\title{
Rifting consequences of three plate separation
}

\author{
Jean-Claude Sibuet \\ Ifremer Centre de Brest \\ Shiri Srivastava \\ Atlantic Geoscience Centre, Geological Survey of Canada
}

\begin{abstract}
Submarine sedimentary basins parallel to the trends of passive continental margins are well explained by tensional processes between two lithospheric plates. This leaves open the enigma of many basins which strike across margins. We use examples from the North Atlantic to show that such basins may be formed during the initial rifting stage due to enhanced lithospheric thinning caused by the separation of three plates. We suggest that volcanics can be emplaced in these basins and, in the extreme case, where mantle temperature and consequently the degree of partial melting are particularly high, that basaltic flows can be thick enough to fill and hide the basins.
\end{abstract}

\section{Introduction}

In 1969, McKenzie and Morgan (1969) defined a triple junction (TJ) as the intersection of three plate boundaries. They described different types of TJs in the oceanic domain depending on the nature of the plate boundaries (ridge, transform fault or trench) and their stabilities through time. Later on, Burke and Dewey (1973) suggest that bends in rifted Atlantic-type margins may reflect the distribution of TJs at the time continents parted and plume traces on continents lead away from the former TJs. In fact, the TJ concept cannot be applied strictly to the continental domain because it assumes no internal plate deformation. However, continental disruption involving three plates but not systematically the existence of a plume, as suggested by Burke and Dewey (1973), can be expected to produce increased localized extension and subsequent subsidence at the intersection of the plates.

\section{Rifting processes at three plate junction}

During the formation of continental basins and margins, extension is distributed over the whole width of the rift system and locally increases with depth (Le Pichon and Sibuet, 1981). Whatever may be the rifting mechanism between two plates, basins formed over thinned crust are parallel to the initial plate boundaries. In the case of three plates, in the immediate vicinity of the plate corners, a small portion of continental lithosphere of each of the three plates experiences a greater amount of total extension because of the cumulative extension on each side of the plate corners. If

Copyright 1994 by the American Geophysical Union.

Paper number 93GL03304

0094-8534/94/93GL-03304\$03.00 the three plates meet at $120^{\circ}$ and if each arm stretches by a factor $B$, the amount that the continental lithosphere has stretched within the triple junction area is $B^{2}$ (White and Latin, 1993). Thus, extension increases oceanward (Fig. 1a and $b$ ), forming V-shaped basins on thinned continental crust and possibly on oceanic crust in their deepest portions. The basins, which may be intruded by volcanics (White and Latin, 1993), are open oceanward and closed near the hinge line. The geographical extent of such basins depends on the final width of the continental margins and on the angle of the initial plate corner. When this angle decreases, the amount of total extension in the V-shaped basins increases. Local extension is maximum along the three longitudinal axes of the V-shaped basins (Fig. 1b) and continuously increases during rifting. Moreover, local extensional rates could also differ on each side of the axes. In this hypothesis, the axes of the V-shaped basins are transfer faults (Le Pichon and Sibuet, 1981; Gibbs, 1984), that is, shear faults with a variable horizontal offset. The offset generally increases from zero near the undeformed continental crust to a maximum close to the ocean-continent boundary. Both the axes of Vshaped basins and the oceanic TJ trajectories are limits of domains formed or deformed between different plate pairs. The major difference between these two types of features is that the axes of $\mathrm{V}$-shaped basins are continuously active features during rifting whereas oceanic TJ trajectories are fossil from the moment of their creation.

\section{Tests of the model}

The North Atlantic is a good testing ground for the hypothesis of $\mathrm{V}$-shaped basin formation because ocean widening there has been associated with the functioning of several TJs. One of these existed west of the Bay of Biscay during the initial stages of rifting and seafloor spreading between the three plates North America (NAM), Europe (EU) and Iberia (IB) (Fig. 2). The reconstruction of the North Atlantic for chron 330 ( $80 \mathrm{Ma})$ marks the end of the functioning of the TJ (Verhoef et al., 1986; Srivastava et al., 1990a and b; Sibuet and Collette, 1991). Fossil oceanic TJ traces existed between these plates from 118 to $80 \mathrm{Ma}$ and are systematically associated with basement relief as shown by conventional or swath bathymetric data, and by magnetic and continuous seismic reflection records (Sibuet and Collette, 1991; Sibuet et al., 1993b and 1994; Srivastava et al., 1993).

Before the onset of spreading (118 Ma), when extension occurred in the continental crust between the NAM, EU and IB plates (Srivastava et al., 1990a and b; Sibuet, 1987; Welsink et al., 1990), V-shaped basins would, according to 

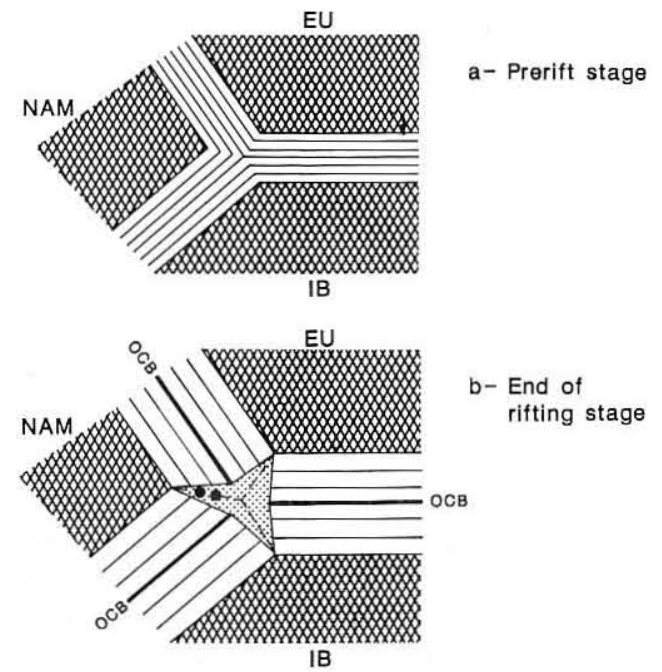

$b-$ End of rifting stage

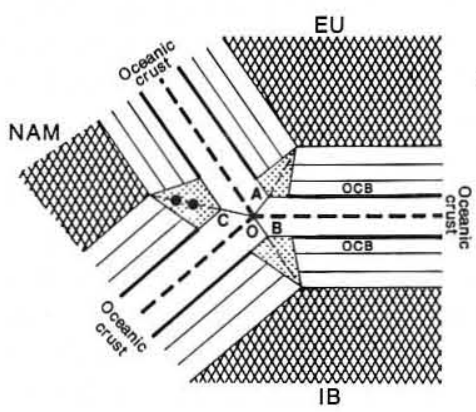

c- Drifting stage

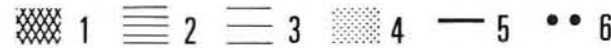

Fig. 1. Schematic diagram of the geographical distribution of extension between North America (NAM), Europe (EU) and Iberia (IB): a) before rifting, showing present-day continental crust (1) and continental crust which will be thinned during rifting (2), b) at the end of the rifting phase, showing the formation of thinned continental crust between plates (3) and V-shaped basins (4) located on thinned continental crust and eventually on oceanic crust in the vicinity of the TJ, c) during drifting stage, fossil TJ trajectories appear in the oceanic domain. A, B and C are conjugate points located at the oceancontinent boundary. Basins trend from close to plate corners across continental margins and are open oceanward. (5): ocean-continent boundary (OCB). (6): location of volcanics.

our model, have formed on each plate close to the initiation of the oceanic TJ (Fig. 2). A V-shaped basin, which we name here King Arthur Basin due to the close proximity of the tabular feature King Arthur Castle (Laughton et al., 1975), exists on the European side (Fig. 3). It is $100 \mathrm{~km}$ wide at the deep oceanic end and over $200 \mathrm{~km}$ long. Nothing has been published about the origin of this basin. However, the line drawing of the MCS profile CM13 (Fig. 3), as well as the interpretation of 8 other existing seismic lines shot across the basin at different azimuths, confirm the existence of this Vshaped depression partially filled of sediments. There, synrift sediments are late Jurassic to early Albian age (Montadert et al., 1979). On the north-western Iberian margin, the Interior basin is of approximately the same size as the King Arthur basin (Fig. 3). Numerous MCS seismic profiles have been acquired and interpreted (e.g. Murillas et al., 1990). The
Interior basin is strictly confined to the portion of the depression located between 70 and $140 \mathrm{~km}$ on profile OC106 (Montadert et al., 1979, Fig. 3) though a broad depression exists between the Galicia bank and the Galicia shelf. Murillas et al. (1990) have shown that the initial subsidence began during the Triassic but, later on, during the Jurassic and early Cretaceous, the basin experienced several episodes of extension. However, the main rifting episode occurred during Valanginian and Aptian times (130 to $118 \mathrm{Ma}$ ). No volcanic intrusions have been reported in these two European basins. On the Flemish Cap margin, the only existing seismic profile was shot by the Institute of Oceanographic Sciences. It shows the existence of a small bathymetric depression $(\mathrm{km}$ 65 , IOS profile 294, Fig. 3) which is not evidenced on the bathymetric map (Fig. 3) mostly because bathymetric data are too scarce, but also the presence of a sedimentary basin which appears very large because of the obliquity of the profile with respect to the orientation of the basin. Though the seismic profile parrallels the continental slope in its southwestern portion, we think that a V-shaped basin exists beneath the continental slope (Fig. 3) and is intruded by volcanics as confirmed by the $200 \mathrm{nT}$ associated positive magnetic anomaly (Parson et al., 1985). We refer to this basin as the Erable basin (Sibuet et al., 1993a; Srivastava et al., 1993). As the continental margin is very narrow there, the Erable basin is short $(70 \mathrm{~km})$ compared with the more than $200 \mathrm{~km}$ long basins on the European side.

Two of the three V-shaped basins, particularly the Interior basin, do not begin precisely at the corners of the undeformed pieces of continents and do not terminate at the beginning of the oceanic fossil TJ trajectories (Fig. 2). It would not be expected that there is ideal coincidence of the

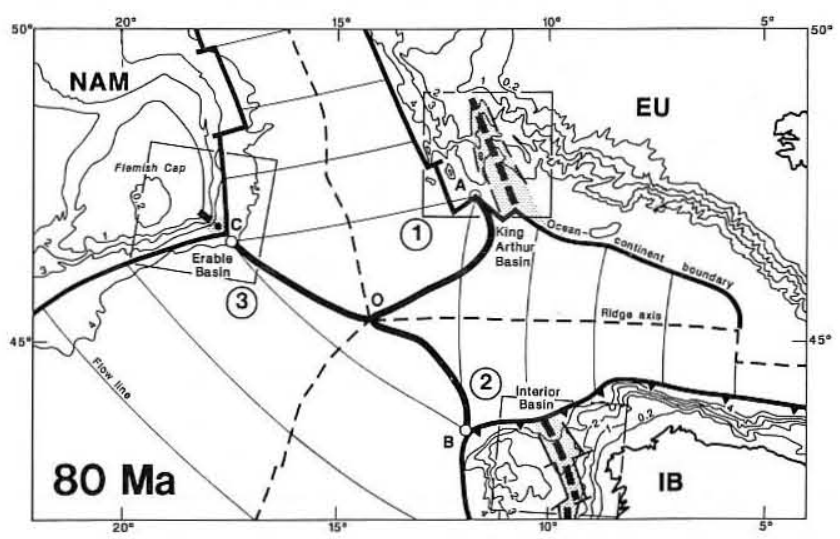

Fig. 2. Reconstruction at chron $33 \mathrm{o}(80 \mathrm{Ma})$ relative to Europe (Sibuet and Collette, 1991). 1-km bathymetric contour intervals from Lallemand and Sibuet (1986) and from the bathymetric map east of Canada (Canadian Hydrographic Service, 1984). At the end of opening of the Bay of Biscay, the RRR triple junction was located at $\mathrm{O}$. A, B and C are conjugate points (Sibuet and Collette, 1991) located at the ocean-continent boundary. Thick continuous lines joining these points to $\mathrm{O}$ are the oceanic fossil TJ trajectories. Thick dashed lines are the axes of V-shaped basins (dotted areas) where local extension is maximum. Flow lines indicate the mean relative motion of plates since the onset of spreading. The location of the three insets of figure 3 is shown. 
(1) King Arthur Basin

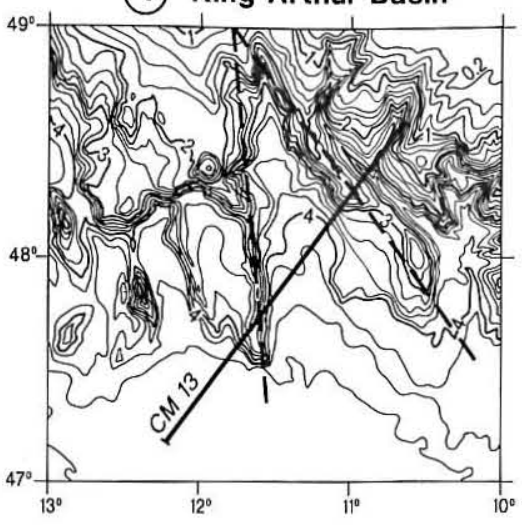

(2) Interior Basin

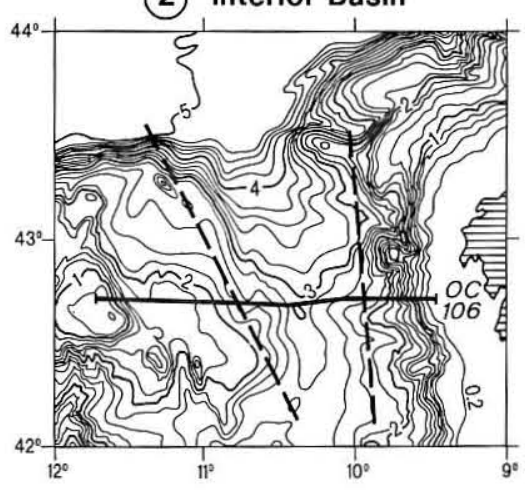

(3) Erable Basin

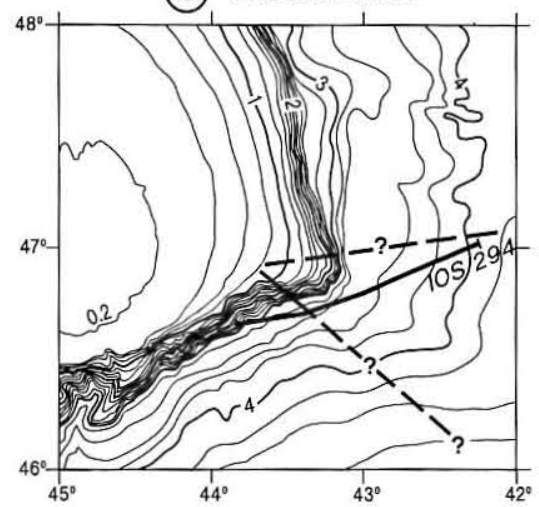

sw

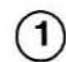

King Arthur Basin

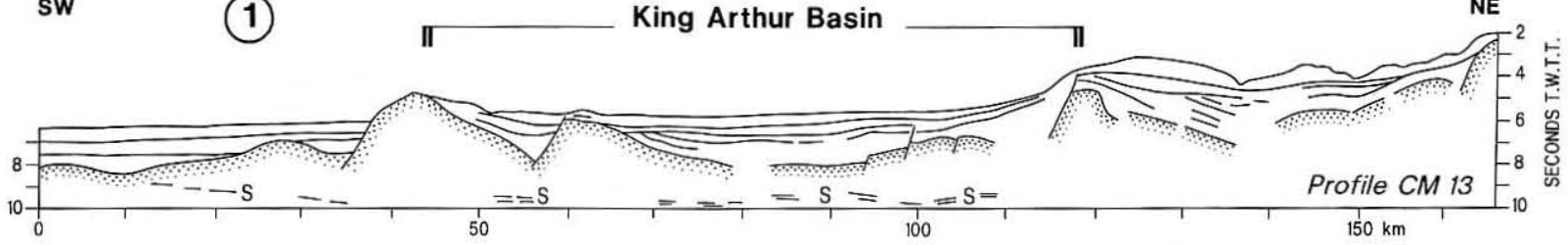

w

Galicia Bank

(2)

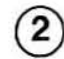

Interior Basin

E

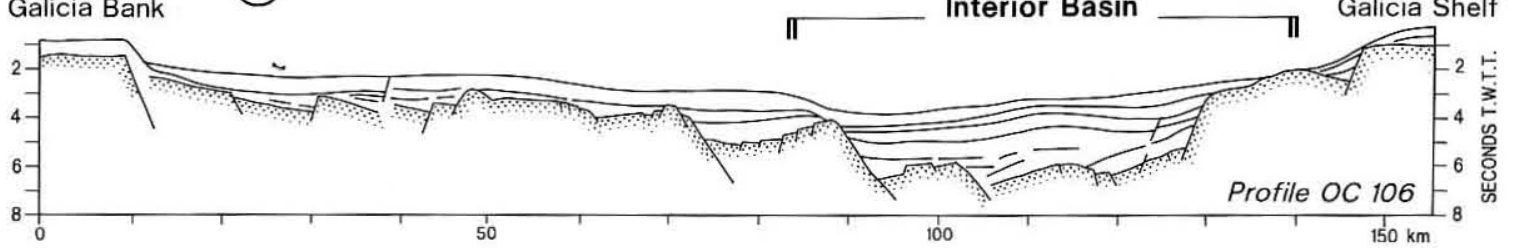

sw

(3)

Erable Basin

NE

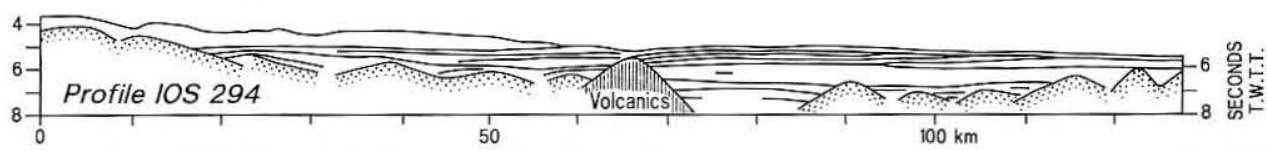

Fig. 3. Enlarged bathymetric insets of the three V-shaped basins (dashed lines). Three significant MCS seismic profiles are located on the latest available bathymetric maps from Sibuet et al. (1993b and 1994) and Lallemand and Sibuet (1986) for insets 1 and 2, from the Canadian Hydrographic Service (1984) for inset 3. Contour interval is $200 \mathrm{~m}$ and labels are every km. The seismic line drawings show that the three basins are associated with a bathymetric depression. Note that the bathymetric map of the Erable Basin is not enough precise to display the depression. Dotted areas correspond to the prerift basement and vertical bars to the volcanic feature which appears in the Erable basin. The intacrustal S reflector is only seen on profile CM13.

basin axes with TJ trajectories, since initial rifting would take place preferentially where zones of weakness exist nearby. Although there is no direct evidence of the details of mechanical disruption in the thinned continental domain or of the synchronism of separation of plate pairs, extension between three plates during continental rifting offers a plausible general explanation for the formation of many sedimentary basins trending across continental margins. For example, the model predicts that the separation of the Rockall, Greenland and NAM plates would give rise to such basins at the south-western tip of Rockall (southwest of the Edoras plateau; Roberts et al., 1979) and south of Cape Farewell (gravity map; Srivastava et al., 1988). No third basin is expected on the NAM plate because of uninterrupted linearity of the margin at the TJ intersection. The Parana trap may be an extreme example of a major depression associated with initial V-shaped basins formed between three plates
(Sibuet et al., 1984; Unternehr et al., 1988) in the continental domain. There, high mantle temperatures and consequent high degrees of partial melting have led to the overflow and masking of the basins by flood basalts.

Acknowledgments. We thank D. Masson and B. Whitmarsh who provided us copies of the Institute of Oceanographic Sciences seismic profile 294 shot on the Flemish Cap margin. Charlotte Keen, Dan MacKenzie, David Needham and Jap Verhoef offered very helpful suggestions and comments.

\section{References}

Burke, K. and J.F. Dewey, Plume generated triple junctions: key indicators in applying plate tectonics to old rocks, $J$. of Geology, 81, 406-433, 1973. 
Canadian Hydrographic Service, General bathymetric chart of the oceans, 5.04 and 5.08, Ottawa, Canada, 1984.

Gibbs, A.D., Structural evolution of extensional basin margins, J. Geol. Soc. London, 141, 609-620, 1984.

Lallemand S. and J.-C. Sibuet, Tectonic implications of canyon directions over the north-east Atlantic continental margins, Tectonics, 5, 1125-1143, 1986.

Laughton A.S, D.G. Roberts and R. Graves, Bathymetry of the northeast Atlantic: Mid-Atlantic ridge to southwest Europe, Deep Sea Res., 22, 791-810, 1975.

Le Pichon X. and J.-C. Sibuet, Passive margins: a model of formation, J. Geophys. Res., 86, 3708-3720, 1981.

McKenzie D.P. and W.J. Morgan, Evolution of triple junctions, Nature, 224, 125-133, 1969.

Montadert L., O. de Charpal, D. Roberts, P. Guennoc, and J.C. Sibuet, Northeast Atlantic passive margins: rifting and subsidence processes. In Talwani M., Hay W.W., and Ryan W.B.F. (eds), Deep Drilling results in the Atlantic Ocean: continental margins and paleoenvironment, $\mathbf{M}$. Ewing Series 3, American Geophysical Union, Washington, 164-186, 1979.

Murillas J., D. Mougenot, G. Boillot, M.C. Comas, E. Banda and A. Mauffret, Structure and evolution of the Galicia Interior basin (Atlantic western Iberian continental margin), Tectonophysics, 184, 297-319, 1990.

Parson L.M., D.G. Masson, C.D. Pelton and A.C. Grant, Seismic stratigraphy and structure of the east Canadian continental margin between 41 and $52^{\circ} \mathrm{N}$, Canadian J. of Earth Sc., 22, 686-703, 1985.

Roberts D.G., L. Montadert and R.C. Searle, The western Rockall plateau: stratigraphy and structural evolution, In Montadert L., Roberts D.G. et al., Init. Rep. of the Deep Sea Drill. Proj., 48, U.S. Government Printing Office, Washington, 1061-1088, 1979.

Sibuet J.-C., Contribution à l'étude des mécanismes de formation des marges continentales passives, Thèse de Doctorat d'Etat, Université de Bretagne Occidentale, Brest, 351 p., 1987.

Sibuet J.-C. and B.J. Collette, Triple junctions of Bay of Biscay and North Atlantic: new constraints on the kinematic evolution, Geology, 19, 522-525, 1991.

Sibuet J.-C., W.W. Hay, A. Prunier, L. Montadert, K. Hinz and J. Fritsch, Early evolution of the South Atlantic: role of the rifting, In Sibuet J.-C., Hay W.W. et al., Init. Rep. of the Deep Sea Drill. Proj., 75, U.S. Government Printing Office, Washington, 469-481, 1984.

Sibuet J.-C., S.P. Srivastava, M.-O. Beslier, K.C. Coflin, J.-P. Le Formal, and V. Louvel, Multichannel seismic survey of passive margins around Flemish Cap (E Newfoundland): a French-Canadian collaborative program, Terra abstracts, 5, 199, 1993a.
Sibuet J.-C., S. Monti, J.-P. Réhault, C. Durand, E. Gueguen, and V. Louvel, Quantification de l'extension liée à la phase pyrénéenne et géométrie de la frontière de plaques dans la partie ouest du golfe de Gascogne, C. R. Acad. Sci. Paris, 317, 2, 1207-1214, 1993b.

Sibuet J.-C., S. Monti, and G. Pautot, Présentation d'une carte bathymétrique du golfe de Gascogne, C. R. Acad. Sci. Paris, 1994, in press.

Srivastava S.P., D. Voppel and B. Tucholke, Geophysical atlas of the North Atlantic between $50^{\circ}$ to $72^{\circ} \mathrm{N}$ and $0^{\circ}$ to $65^{\circ} \mathrm{W}$, Deutsches Hydrographisches Institut, Hamburg, $\mathrm{Nb} 2302,1988$.

Srivastava S.P., W.R. Roest, L.C. Kovacs, H. Schouten, K. Kligord, J. Verhoef and R. Macnab, Iberian plate kinematics: a jumping plate boundary between Eurasia and Africa, Nature, 344, 756-759, 1990a.

Srivastava S.P., W.R. Roest, L.C. Kovacs, G. Oakey, S. Levesque, J. Verhoef and R. Macnab, Motion of Iberia since the late Jurassic: results from detailed aeromagnetic measurements in the Newfoundland basin, Tectonophysics, 184, 229-260, $1990 \mathrm{~b}$.

Srivastava S.P., K. Coflin, and J.-C. Sibuet, Multichannel seismic survey in the Newfoundland Basin: a CanadianFrench collaboration, GAC-MAC joint annual meeting, Edmonton, Alberta, Canada, May 17-19, 1993, abstract, 1993.

Unternehr P., D. Curie, J.-L. Olivet, J. Goslin and P. Beuzart, South Atlantic fits and intraplate boundaries in Africa and south America, Tectonophysics, 155, 169-179, 1988.

Verhoef J., B.J. Collette, P.R. Miles, R.C. Searle, J.-C. Sibuet and C.A. Williams, Magnetic anomalies in the north-east Atlantic ocean, Mar. Geophys. Res., 8, 1-25, 1986.

Welsink H.J., S.P. Srivastava and A.J. Tankard, Basin architecture of the Newfoundland continental margin and its relationship to ocean crust fabric during extension, in Tankard A.J., Balkwill H.R. (eds), Extensional tectonic and stratigraphy of the north Atlantic margins, Am. Assoc. Petroleum Geol. Mem., 46, Tulsa, 197- 213, 1990.

White N. and D. J. Latin, Subsidence analyses from the North Sea "triple junction", J. Geol. Soc. London, 150, 473-488, 1993.

J.-C. Sibuet, Ifremer Centre de Brest, B.P. 70, 29280 Plouzané, France; internet: jcsibuet@ifremer.fr

S. Srivastava, Atlantic Geoscience Centre, Geological Survey of Canada, P.O. Box 1006, Dartmouth, N.S., B2Y 4A2, Canada; internet: Srivasta@agcrr.bio.ns.ca

(Received June 7, 1993; revised October 22, 1993; accepted November 22, 1993.) 